\title{
セメント調合原料の迅速分析法へのケイ光 $\mathbf{X}$ 線の利用
}

\author{
河 崎 仁*, 浅田 栄一**
}

粘土質調合原料中の酸化鉄, 酸化ケイ素, 酸化アルミニウムの定量抢よびスラリーと石灰石中の酸化 カルシウムの定量に，ケイ光X線分析を利用する方法について検討を行なった。

試料調製は，粉末原料老そのまま加圧成型する方法によった。

酸化鉄, 酸化カルシウムの分析では, 検量線からの偏差は, 化学分析法における分析者 2 名の場合の 標準偏差と同程度の值が容易淂られた。

酸化ケイ素, 酸化アルミニウムの分析では, タブレット調製(サンプリング)でとの測定值のバラッキ が比較的大きいととが観察され, サンプリングを繰返す必要が認められた。 ての理由は, $\operatorname{SiK} \alpha, \operatorname{AlK} \alpha$ の測定㐿がきわ好薄いととに起因するものであると考えられた。

酸化ケイ素, 酸化アルミニウムの分析の際, 分光結晶に ADP (ammonium dihydrogen phosphate)

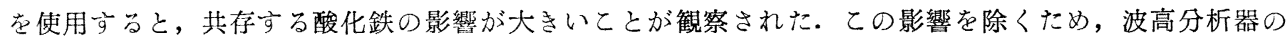
ウインドウ幅をせばめる方法と分光結晶に EDDTを使用する方法および数式を用いて補正する方法に ついて検討を行なった。 その結果，ADP を用いても，ウインドウ幅をせばめる方法だけで，検量線か らの偏差が化学分析法に打ける標準偏差（分析者 2 名の場合）とほぼ同程度の值になるととが明らかと なったが, 酸化ケイ素の場合には, 数式による補正をさらに加えることによって, 改善され $\left(\mathrm{SiO}_{2} 62\right.$ $67 \%$ で $\sigma=0.29 \%)$, 両者の併用がすぐれた方法であることが結論された.

\section{1 緒言}

セメント調合原料の分析法の迅速化のた氻に, ケイ光 X線を利用しょうという研究は, 既に数多くなされてき た1) ${ }^{14)}$.

しかし，そこでは，試料が粉末混合物であることを主 な理由として、いくつかの困難に直面した. すなわち, ある分析元素の含有量が同じであっても，その元素のケ イ光 $\mathrm{X}$ 線強度が異なるという問題である. これは，(1) 原料の産地が異なっててその鉱物学的性状が相違するた 为に生ずる影響，(2) 粉末の粒子間, または粒子内の成 分分布の相違のために生ずる影響, (3) 共存元素の影響 などの諸影響によるとされている1222.

その解決法として，つぎの二つの方法が提案された. すなわち，(I)燒成操作2)または融郕を用いての溶融操 作1)によって試料を均質化させ，(1)，(2) の原因に基づ くケイ光 X線の強度の不安定性を除去する方法と, (II) 試料粉末をそのまま粉确加圧成型してケイ光X $\mathrm{X}$ 線強度を 測定するものであるが, 別に標準試料として多種類の系

* 日本セメントK.K. 埼玉工場 : 埼玉県入間郡日高町 原宿

** 東京工業試験所 : 東京都渋谷区本町 1 丁目
統のものを用意しておき，分析にあたって，そのうちか ら適当な標準物と検量線とを選ぶ方法である。，後者は， type standardization (分類別標準法) とよばれる1).

この研究においては, 日本セメントK.K.埼玉工場の 工程管理の迅速化と簡易化とをはかることを対象とした が, 繁雑な試料の熱処理などの前処理は避け, 単純な加 圧成型法による分析法を確立することを目標とした。

幸いに, 当工場に掠いて注, 粘土渏玉県東松山市付 近，ローム注同県高麗川付近のものを一定して使用しつ づけているもので, 長期間にわたり, 調合原料の鉱物的 性状はほぼ安定していることが期待できた。したがっ て, 直ちに上述の (2), (3) の影響について考察すること が可能であると予想された.

これらの方法にしたがい検討した結果, 当分析法では 調合原料産地が一定している限り, 繁雑な前処理を行な わなくとも, 各単一の検量線で必要な精度と正確度とが 得られることが明らかとなった。

以下，これについて報告する.

\section{2 測定装置}

Norelco $100 \mathrm{kV}$ constant potential X-ray spectrograph を使用した. 
各部の構成はつぎのと扣り.

$\mathrm{X}$ 線管：タングステン対陰極.

分光結晶： $\mathrm{FeK} \alpha$ に対して $\mathrm{LiF}, \mathrm{CaK} \alpha$ に対して $\operatorname{EDDT}, \operatorname{SiK} \alpha, \operatorname{AlK} \alpha$ に対して $\operatorname{ADP}$ (実験 I, II, III) および EDDT (実験 III).

検出器：ガスフロ一型比例計数管.

波高分析器：FeK $\alpha$ に対して積分方式, その他はすべ て微分方式で使用.

$\mathrm{X}$ 線通路: FeK $\alpha$ に対しては空気, その他はすべてへ リウムガス $15 \mathrm{ft}^{3} / \mathrm{hr}$ を流通させて測定した.

な打，測定したケイ光 $\mathrm{X}$ 線 $\mathrm{FeK} \alpha, \operatorname{CaK} \alpha, \operatorname{SiK} \alpha$, $\mathrm{AlK} \alpha$ はすべて一次線を使用したもので，その強度值は 比較試料 (reference standard sample) と分析試料 とを交互に测定して，その比の值で示してある.

\section{3 試料}

酸化カルシウムの分析では，石灰石とスラリーとを対 象にし, 酸化鉄, 酸化ケイ素, 酸化アルミニウムの分析 では，粘土質調合原料を試料とした.

試料は乳鉢で粉砕し，つぎの粒度とした，石灰石およ びスラリー： 88 micron 全通, 粘土質調合原料： 88 micron 残分 $20 \%$.

各試料の化学分析值を Table I, Table II, Table III に示す.

Table I Chemical analysis of limestone and slurry $(\%)$

\begin{tabular}{|c|c|c|c|c|c|c|c|c|}
\hline No. & Name & Ig. loss & $\mathrm{SiO}_{2}$ & $\mathrm{Al}_{2} \mathrm{O}_{3}$ & $\mathrm{Fe}_{2} \mathrm{O}_{3}$ & $\mathrm{CaO}$ & $\mathrm{MgO}$ & To \\
\hline 1 & Buko & 43.19 & 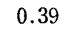 & 0.17 & 2 & 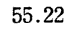 & 3 & 42 \\
\hline 2 & Hiks & & & & & & & \\
\hline 3 & Yoshizaw & & & & & & & \\
\hline 4 & Chi & 3 & 4 & & 30 & & 0.42 & 97.99 \\
\hline 5 & Chi & 4 & 5 & 2 & 1 & 50 & 0 & 99.23 \\
\hline \multirow[t]{3}{*}{6} & Nekoya & & 6.78 & & & & 0.77 & 99.07 \\
\hline & Slur & & 14.84 & & 2.03 & & 0.63 & 99.27 \\
\hline & Slurry M & 34.60 & 15.45 & 1.97 & 2.69 & 43.86 & 0.55 & 99.12 \\
\hline
\end{tabular}

Table II Chemical analysis of slip (\%) (Raw mix of clay and pyrites cinder)

\begin{tabular}{ccrrrrrr}
\hline Sample & Ig. loss & $\mathrm{SiO}_{2}$ & $\mathrm{Al}_{2} \mathrm{O}_{3}$ & $\mathrm{Fe}_{2} \mathrm{O}_{3}$ & $\mathrm{CaO}$ & $\mathrm{MgO}$ & Total \\
\hline $\mathrm{A}$ & 6.26 & 66.68 & 11.87 & 7.89 & 2.28 & 1.39 & 96.37 \\
$\mathrm{~B}$ & 4.79 & 67.80 & 12.92 & 8.24 & 2.15 & 1.44 & 97.34 \\
$\mathrm{C}$ & 6.41 & 65.98 & 11.98 & 8.58 & 2.31 & 1.47 & 96.73 \\
$\mathrm{D}$ & 2.78 & 71.64 & 8.45 & 11.71 & 1.51 & 1.30 & 97.39 \\
$\mathrm{E}$ & 10.58 & 48.80 & 27.58 & 10.26 & 1.13 & 0.85 & 99.20 \\
$\mathrm{~F}$ & 2.83 & 70.92 & 4.75 & 18.73 & 0.55 & 0.64 & 98.42 \\
$\mathrm{~A}^{\prime}$ & 5.01 & 69.26 & 13.20 & 8.00 & 1.59 & 1.38 & 98.44 \\
$\mathrm{~B}^{\prime}$ & 9.44 & 55.20 & 21.62 & 11.62 & 0.44 & 0.74 & 99.06 \\
$\mathrm{C}^{\prime}$ & 7.69 & 62.78 & 17.28 & 8.00 & 1.09 & 1.18 & 98.02 \\
$\mathrm{D}^{\prime}$ & 7.80 & 60.00 & 17.70 & 11.86 & 0.76 & 0.80 & 98.92 \\
$\mathrm{~F}^{\prime}$ & 6.34 & 66.00 & 14.90 & 7.82 & 1.44 & 1.52 & 98.02 \\
$\mathrm{G}^{\prime}$ & 7.53 & 62.82 & 17.82 & 7.90 & 1.12 & 1.12 & 98.31 \\
\hline & & & & & & &
\end{tabular}

Table III Chemical analysis of slip (\%) (Raw mix of clay and pyrites cinder)

\begin{tabular}{cccccccc}
\hline \hline Sample & $\mathrm{Ig}$. loss & $\mathrm{SiO}_{2}$ & $\mathrm{Al}_{2} \mathrm{O}_{3}$ & $\mathrm{Fe}_{2} \mathrm{O}_{3}$ & $\mathrm{CaO}$ & $\mathrm{MgO}$ & Total \\
\hline $\mathrm{A}^{\prime \prime}$ & 9.12 & 63.28 & 13.62 & 9.33 & 1.74 & 1.10 & 98.19 \\
$\mathrm{~B}^{\prime \prime}$ & 8.96 & 64.33 & 12.98 & 8.59 & 1.89 & 1.26 & 98.01 \\
$\mathrm{C}^{\prime \prime}$ & 8.65 & 65.44 & 11.87 & 8.29 & 2.02 & 1.35 & 97.62 \\
$\mathrm{D}^{\prime \prime}$ & 8.48 & 66.19 & 11.30 & 7.86 & 2.43 & 1.33 & 97.59 \\
$\mathrm{E}^{\prime \prime}$ & 8.49 & 67.43 & 10.20 & 7.42 & 2.54 & 1.44 & 97.52 \\
$\mathrm{~F}^{\prime \prime}$ & 8.38 & 64.93 & 12.29 & 9.25 & 1.99 & 1.20 & 98.04 \\
$\mathrm{G}^{\prime \prime}$ & 8.25 & 65.92 & 11.37 & 9.76 & 1.90 & 1.17 & 98.37 \\
$\mathrm{H}^{\prime \prime}$ & 9.28 & 63.16 & 13.52 & 8.41 & 1.91 & 1.20 & 97.48 \\
$\mathrm{I}^{\prime \prime}$ & 8.01 & 67.07 & 10.33 & 8.36 & 2.35 & 1.37 & 97.49 \\
$\mathrm{~J}^{\prime \prime}$ & 9.28 & 63.20 & 13.77 & 7.56 & 2.16 & 1.37 & 97.34 \\
$\mathrm{~K}^{\prime \prime}$ & 8.85 & 65.30 & 12.25 & 7.27 & 2.39 & 1.40 & 97.46 \\
\hline
\end{tabular}

いずれもアルミニウムリングをわくとし，約 $800 \mathrm{~kg} /$ $\mathrm{cm}^{2}$ で加圧成型し, タブレットとしたものについて測定 した。

$$
4 \text { 実 験 I }
$$

測定条件をつぎのように選び，各成分％とケイ光 $\mathrm{X}$ 線強度との関係を求めた.

\section{$4 \cdot 1$ 測定条件}

(1) X線管条件： $\mathrm{FeK} \alpha$ の測定には $30 \mathrm{kV}-10 \mathrm{~mA}$ とし, $\mathrm{CaK} \alpha, \operatorname{SiK} \alpha, \operatorname{AlK} \alpha$ の測定には $50 \mathrm{kV}-35 \mathrm{~mA}$ とした.

（2）波高分析器の条件: $\mathrm{FeK} \alpha$ の測定には, エスケ 一プ・ピークを含めての積分方式としたが, $\operatorname{CaK} \alpha$, $\operatorname{SiK} \alpha, \operatorname{AlK} \alpha$ では微分方式とし，メイン・ピークの全波 高をカバーして計数できるようウインドウ電圧を $30 \mathrm{~V}$ (当装置の最大值)とした.

(3) 各試料からは，つぎの個数のサンプリングを行 ない測定した. 石灰石, スラリーおよび Table II に示 す粘土質調合原料においては各 1 個, Table III に示す 粘土質調合原料では各 3 個. 後者では, その平均值をも ってX線強度とし, 図にプロットした。

\section{$4 \cdot 2$ 測定結果}

Fig. 1〜Fig. 4 に示した.

\section{3 考 察}

（1）酸化鉄に対して，成分\%とケイ光X線強度との 関係は高度の直線性を示した(Fig. 1). マトリックスの 影響はきわめてわずかである。

(2) 酸化カルシウムにおいても, 酸化鉄と同じくマ トリックスの影響はきわめて少なく, 高度の直線性を示 


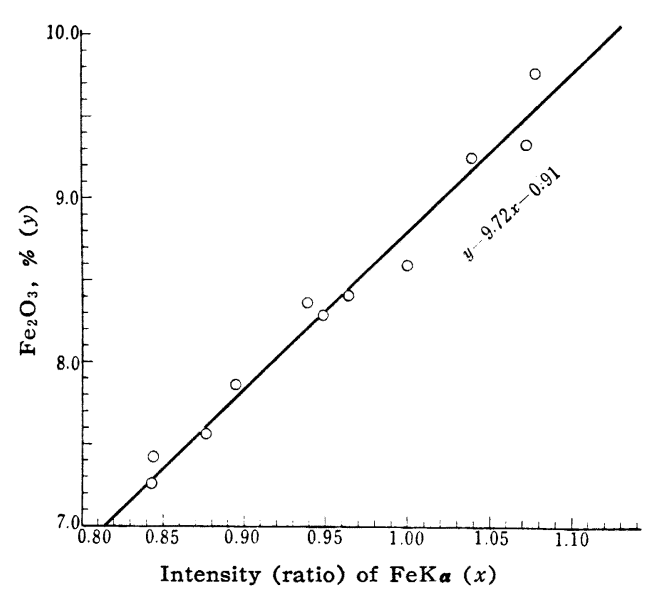

Fig. 1 The intensity ratio and the percentage composition of $\mathrm{Fe}_{2} \mathrm{O}_{3}$ in pressed slip tablets

Condition of measurement

1: X-ray tube, $30 \mathrm{kV} \cdot 10 \mathrm{~mA}$

2: P. H. A., Integral

3: Analysing crystal, LiF

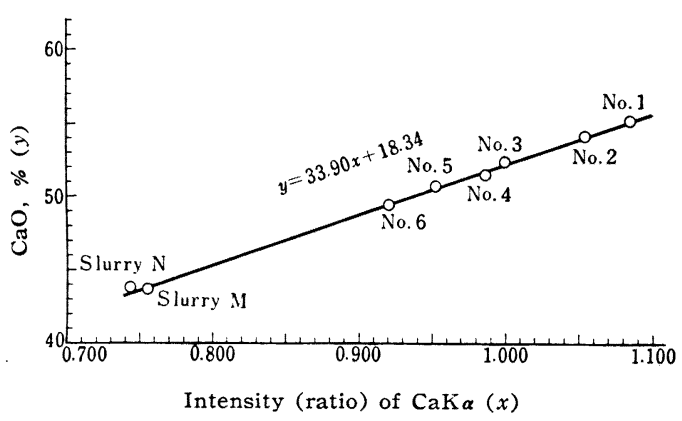

Fig. 2 The intensity ratio and the percentage composition of $\mathrm{CaO}$ in pressed tablets of limestone and slurry

Condition of measurement

1: X-ray tube, $50 \mathrm{kV}-35 \mathrm{~mA}$

2: P. H. A., Differential W. V. $30 \mathrm{~V}$

3: Analysing crystal, EDDT

した(Fig. 2)、孛なわち，石灰石の銘柄のちがい潅察 されず，また，石灰石とスラリ一との間で同一の検量線 が使用できることが明らかとなった。

(3) 前二者の分析誤差：（i 回帰直線(検量線)から の測定点のズレ. (ii) タブレットの調製（サンプリング） ごとの測定值のバラツキ.すなわち，酸化鉄の分析の際 の 1 回のサンプリングの 5 回繰返しに対する標準誤差. (iii) 測定の計数値の統計変動に基づく变動係数から計算 した標準偏差.を Table IV に示した。

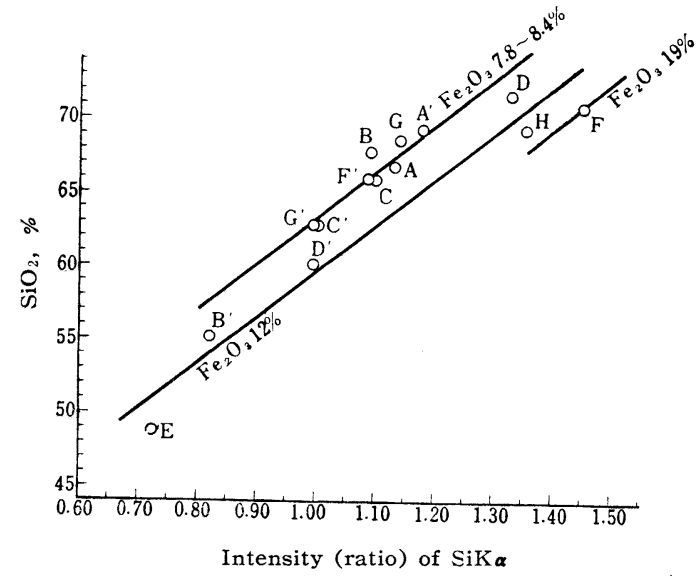

Fig. 3 The intensity ratio and the percentage composition of $\mathrm{SiO}_{2}$ in pressed slip tablets

Condition of measurement

1: X-ray tube, $50 \mathrm{kV}-35 \mathrm{~mA}$

2: P. H. A., Differential W. V. 30V

3: Analysing crystal, ADP

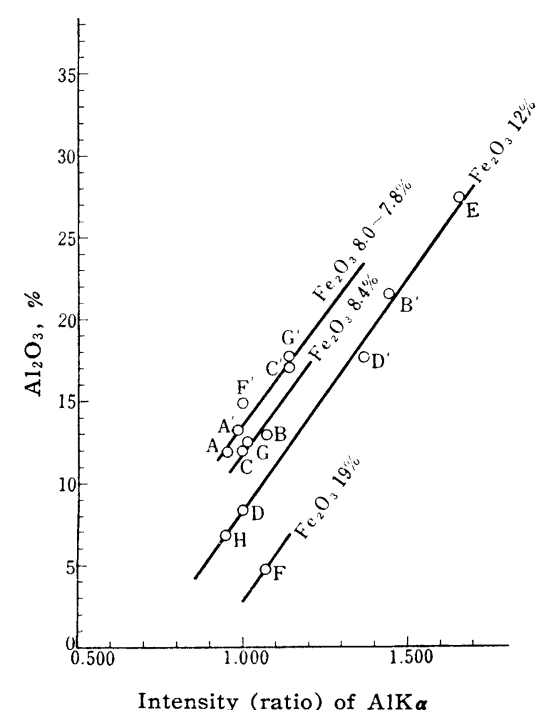

Fig. 4 The intensity ratio and the percentage composition of $\mathrm{Al}_{2} \mathrm{O}_{3}$ in pressed slip tablets

\footnotetext{
Condition of measurement

1: X-ray tube, $50 \mathrm{kV}-35 \mathrm{~mA}$

2: P. H. A., Differential W. V. $30 \mathrm{~V}$

3: Analysing crystal, ADP
}

ただし，(2) のサンプリングによるバラッキは，5試 料 5 回のサンプリングの測定值の一元配置の誤差項から 求めた值である. 
Table IV Standard deviation

\begin{tabular}{|c|c|c|c|c|c|}
\hline \multirow{2}{*}{$\begin{array}{l}\text { Oxides } \\
\text { to be } \\
\text { deter- } \\
\text { mined }\end{array}$} & \multirow{2}{*}{$\begin{array}{l}\text { Deviation of } \\
1 \text { tablet from } \\
\text { mean of } 5 \\
\text { tablets }(\%)\end{array}$} & \multirow{2}{*}{$\begin{array}{l}\text { Deviation } \\
\text { from } \\
\text { regression } \\
\text { line }(\%)\end{array}$} & \multirow{2}{*}{$\begin{array}{c}\text { Detector } \\
\text { statistics } \\
(\%)\end{array}$} & Chemical & analysis \\
\hline & & & & $\begin{array}{c}\text { Onet } \\
(\%)\end{array}$ & $\begin{array}{c}\text { Two } \\
(\%)\end{array}$ \\
\hline & - & & 0. & -7 & 0.200 \\
\hline $\mathrm{Fe}_{2} \mathrm{O}_{3}$ & 0.068 & 0.131 & 0.002 & 0.078 & 0.128 \\
\hline
\end{tabular}

+ Number of analysts

Table IV から, 酸化鉄, 酸化カルシウムの分析法へ のケイ光X線の利用は, 精度, 正確度の点で, 十分化学 分析法に匹敵するものであることが認められる。

(4) 酸化ケイ素の測定では, 同一の含有量であって も, 共存する酸化鉄の含有量の多いものほど $\operatorname{SiK} \alpha$ の強 度の測定值が高くなっている(Fig. 3).

酸化アルミニウムの場合も同様である(Fig. 4). このように，酸化鉄の含有量にしたがって, $\operatorname{SiK} \alpha$, $\mathrm{A} 1 \mathrm{~K} \alpha$ の強度の測定值が変化する事実が認められた.こ れを解決するため分類別標準法(type standardization) を採用することは，調合原料中の酸化鉄の含有率が連続 的に変化している関係上, 不可能である.

したがって，この影響を除く方法を検討するため，つ ぎの実験 II および IIIを行なった。

\section{5 実 験 II}

$\operatorname{SiK} \alpha$ の測定の際の鉄元素の影響についての原因を調 ベる目的た，金属鉄を試料としたときの, $\operatorname{SiK} \alpha$ の分光 角度位置に回折されるX線の波高分布を測定した 5(a)\}. 分光結晶, 計数管などの諸条件は実験 I と同一 である.

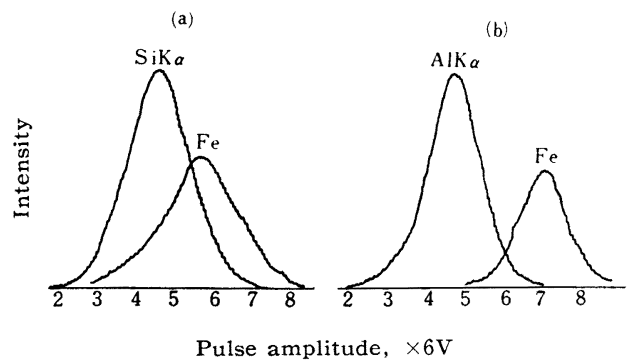

Fig. 5 Pulse height distribution curve

(a) $\mathrm{SiK} \boldsymbol{\alpha}$ and PK $\boldsymbol{\alpha}$ due to ADP crystal excited by iron (b) $\mathrm{A} 1 \mathrm{~K} \alpha$ and $\mathrm{PK} \alpha$ due to ADP crystal excited by iron

こうして得られた波高分有は, $\operatorname{SiK} \alpha$ のとれと比較し てピーク位置はやや高いところにあり，その分布は，大 きく重なり合うことが観察された Fig. 5 (a)\}.

同様にして，A1K $\alpha$ の分光角度に回折されるX線の波
高分布を測定した。結果は同じように $\mathrm{A} 1 \mathrm{~K} \alpha$ と重複す る分布が得られたが, $\operatorname{SiK} \alpha$ の場合よりは分離の程度は 大きかった $\{$ Fig. 5 (b)\}.

このようにして，純鉄学試料として作られた波高分布 は，鉄のK線が分光結晶 ADP 中のリンを励起するため ではないかと考无られた5)ので, リン酸ナトリウムを試 料として, PK $\alpha$ の波高分布を測定したところ, 両者と もこの波高分布に完全に一致することがわかった。

\section{6 実 験 III}

実験 I およびII の結果に基づき，酸化ケイ素および 酸化アルミニウムのケイ光X線分析の際の共存元素の鉄 の影響を除く方法として,つぎの三種の方法が考元られ た.

（i）分光結晶には ADP を用いるが，波高分析器のウ インドウ幅をせばめることによって，励起されたリンの K線を除く方法.（ii）分光結晶として，EDDTを使用 する方法. (iii) 数式的にデータを処理して, 鉄元素の影 響を除く方法.

この三種の方法について検討を行なった。試料には Table III に示す粘土質調合原料を用いた。

\section{$6 \cdot 1$ 波高分析器のウィンドウ幅をせばめて，鉄の影}

\section{響を除く方法（分光結晶 $\mathrm{ADP}$ )}

Fig. 5（a ）（b）の波高分布戍で，ケイ素またはア ルミニウムの波高分布と，鉄によって励起された $\mathrm{PK} \alpha$ の波高分布との交わるところに，ウインドウ幅の上限范 おき，PK $\alpha$ を除く条件で測定を行なった。

6.1.1 波高分析器の条件 $\operatorname{SiK} \alpha$ に刘しては, 下 限電圧 $12 \mathrm{~V}$, ウインドウ幅 $15 \mathrm{~V}$. $\mathrm{A} 1 \mathrm{~K} \alpha$ に刘しては, 下限電圧 $12 \mathrm{~V}$, ウインドウ幅 $18 \mathrm{~V}$.

$6 \cdot 1 \cdot 2$ 測定および結果測定は，各試料につきそ れぞれ 3 個のタブレットを調製して行ない，その平均值 を求的た。

測定結果を Fig. 6-a および 6-bに，諸分析誤差を Table V に示した.ここでタブレット調製ごとの測定 值のバラツキは, 5 試料, 5 回のサンプリングの測定を一 元配置の誤差項ふら求めた值である.

Table V Standard deviation

\begin{tabular}{|c|c|c|c|c|c|}
\hline \multirow{2}{*}{$\begin{array}{l}\text { Oxides } \\
\text { to be } \\
\text { deter- } \\
\text { mined }\end{array}$} & \multirow{2}{*}{$\begin{array}{l}\text { Deviation of } \\
1 \text { tablet from } \\
\text { mean of } 5 \\
\text { tablets }(\%)\end{array}$} & \multirow{2}{*}{$\begin{array}{l}\text { Deviation } \\
\text { from } \\
\text { regression } \\
\text { line }(\%)\end{array}$} & \multirow{2}{*}{$\begin{array}{c}\text { Detector } \\
\text { statistics } \\
(\%)\end{array}$} & \multirow{2}{*}{$\frac{\overbrace{\begin{array}{c}\text { Onet } \\
(\%)\end{array}}^{\text {Chemical }}}{\text {. }}$} & \multirow{2}{*}{$\frac{\text { analysis }}{\begin{array}{c}\text { Two } \\
(\%)\end{array}}$} \\
\hline & & & & & \\
\hline & & 0.405 & 0.300 & 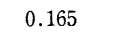 & 0.3 \\
\hline $\mathrm{Al}_{2} \mathrm{O}_{3}$ & 0.485 & 0.303 & 0.250 & 0.203 & 0.246 \\
\hline
\end{tabular}

$\dagger$ Number of analyst 


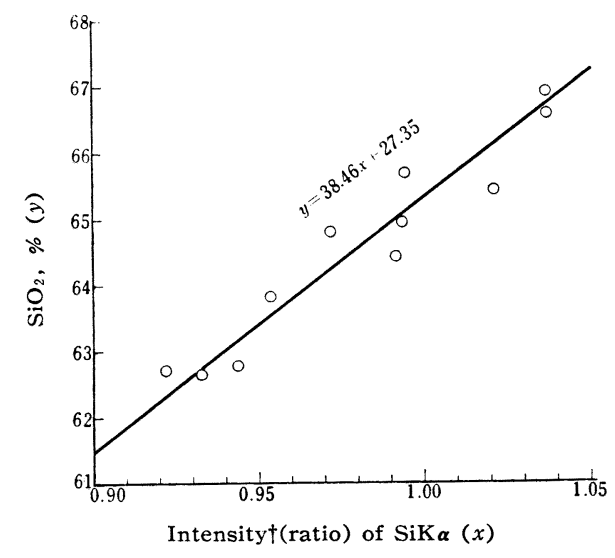

Fig. 6-a The intensity ratio and the percentage composition of $\mathrm{SiO}_{2}$ in pressed slip tablets

Condition of mesurement

1: X-ray tube, $50 \mathrm{kV}-35 \mathrm{~mA}$

2: P. H. A., Differential W. V. $15 \mathrm{~V}$

3: Analysing crystal, ADP

$\dagger$ Mean of three tablets

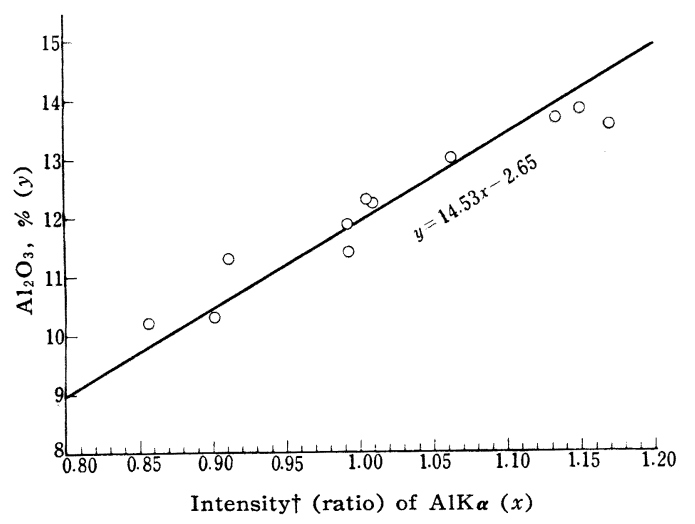

Fig. 6-b The intensity ratio and the percentage composition of $\mathrm{Al}_{2} \mathrm{O}_{3}$ in pressed slip tablets

Condition of measurement

1: X-ray tube, $50 \mathrm{kV}-35 \mathrm{~mA}$

2: P. H. A., Differential W. V. $18 \mathrm{~V}$

3: Analysing crystal, ADP

$\dagger$ Mean of three tablets

6.1.3 考察 Table V を Table IV と比較する と, 酸化鉄の場合より, 精度, 正確度がおちちていること がわかる：この原因としてはつぎの事項があげられる。

（i）サンプリングによる誤差（タブレット調製ごと の誤差）が，酸化鉄の場合に比較して大きいのは，タブ レットの表面にきわめて近い, 薄い層に存在する元素 （ケイ素またはアルミニウム）のケイ光X線だけが測定
されうるということに起因すると考えられる.

一例として, 酸化鉄, 石英, 水酸化アルミニウムなど の $\mathrm{FeK} \alpha, \operatorname{SiK} \alpha, \operatorname{AlK} \alpha$ に対する，単位体積あたりの 吸収係数と, これらによって計算した各ケイ光 X線を99 \%吸収するに必要な厚みとを Table VI にかかげた。

Table VI Absorption coefficient $\left(\sum \mu_{i} \rho_{i}\right)$

\begin{tabular}{cccc}
\hline \hline Lines & $\mathrm{Fe}_{2} \mathrm{O}_{3}$ & $\mathrm{SiO}_{2}$ & $\mathrm{Al}_{2} \mathrm{O}_{3}$ \\
\hline FeK $\boldsymbol{\alpha}$ & 304 & 179 & 118 \\
& $(152) \dagger \dagger$ & $(258)+\dagger$ & $(390)+\dagger$ \\
SiK $\boldsymbol{\alpha} \dagger$ & 8940 & 1750 & 4060 \\
& $(5.2)+\dagger$ & $(26.4)+\dagger$ & $(11.3) \dagger \dagger$ \\
AlK $\boldsymbol{\alpha}$ & 12960 & 2740 & 2540 \\
& $(3.6) \dagger \dagger$ & $(16.9)+\dagger$ & $(18.2) \dagger \dagger$ \\
\hline
\end{tabular}

$\dagger$ Approximate wavelength $=7.08 \AA$

t† Thickness $(\mu)$ of oxides or hydroxide to be able to absorb $99 \%$ of intensity of fluorescent $\mathrm{X}$-rays cited in the left column.

Table VI から, $\operatorname{SiK} \alpha, \operatorname{AlK} \alpha$ の測定では, $\mathrm{FeK} \alpha$ の場合の約 1/6〜1/100 程度の厚みの試料層しか測定し ていないことがわかる. 1 回の測定の標準偏差は, ほぼ 測定層の平方に反比例すると考えられ，バラツキの大き いごとが了解される.したがって，これらの測定では， 正確度を高めるためには数多くのタブレットを調製し， 測定する必要があることが結論された.

(ii) 回帰直線からの偏差が大きい原因としては, 鉄 による影響が十分に除かれていないことが予想された。

\section{$6 \cdot 2$ 分光結晶として EDDT を使用する方法}

波高分析器のウインドウ幅は $24 \mathrm{~V}$ とし, その他の諸 条件は実験 I と同様にした. 測定されたケイ光X線強度 と成分\%との関係を Fig. 7 に示す.

回帰直線からの偏差は, ケイ素に対し $0.67 \%$, アル ミニウムに対して $0.41 \%$ となり，いずれも期待した好 結果が得られなかった。これについては，ウインドウ幅 をせばめるなど，測定諸条件について，さらに検討をす すめる必要がある。

\section{$6 \cdot 3$ 数式的に補正する方法}

$\operatorname{SiK} \alpha$ または $\mathrm{AlK} \alpha$ として測定されたX線強度值か ら，鉄による影響分だけを数式的に差引く方法を検討し た。この補正式の定数は，回帰分析により求めた。

$6 \cdot 3 \cdot 1$ 酸化ケイ素の分析 $\mathrm{SiO}_{2} \%(X)$ は $\mathrm{SiK} \alpha$ の 強度 $x$ および $\mathrm{FeK} \alpha$ の強度 $z$ との間と次式の関係があ ると仮定した。

$X=a+b x+c z$ 


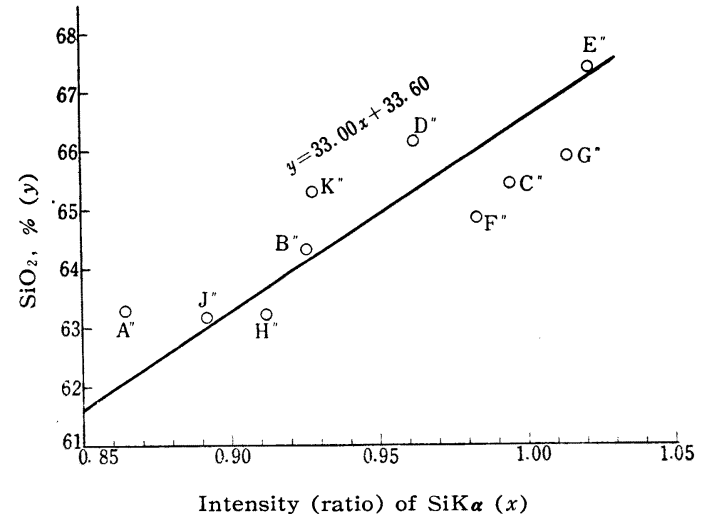

Fig. 7-a The intensity ratio and the percentage composition of $\mathrm{SiO}_{2}$ in pressed slip tablets

Condition of measurement

1: $\mathrm{X}$-ray tube, $50 \mathrm{kV}-35 \mathrm{~mA}$

2: P. H. A, Differential W. V. $24 \mathrm{~V}$

3: Analysing crystal, EDDT

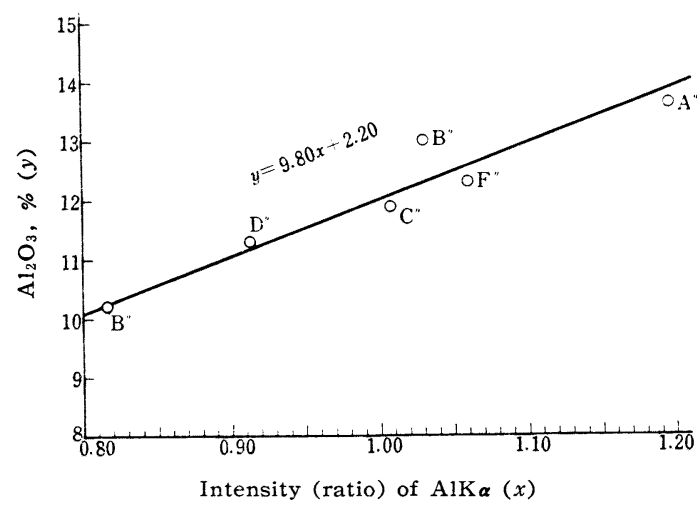

Fig. 7-b The intensity ratio and the percentage composition of $\mathrm{Al}_{2} \mathrm{O}_{3}$ in pressed ship tablets

Condition of measurement

1: X-ray tube, $50 \mathrm{kV}-35 \mathrm{~mA}$

2: P. H. A., Differential W. V. $24 \mathrm{~V}$

3: Ana lysing crysta1, EDDT

（1）における定数 $a ， b, c$ 注重回州分析により求め た. $z$ 注波高分析器のウインドウ幅を $15 \mathrm{~V}$ および $30 \mathrm{~V}$ に調節することにより変化させた。

回帰分析から求めた定数 $a, b, c$ を Table VII に示

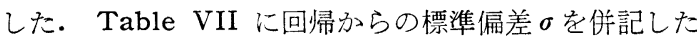
が，この值は，誤差項 $S_{\mathrm{E}}$ を自由度で割り，その平方を 求めた值である.

ウインドウ幅を $15 \mathrm{~V}$ とし, $\operatorname{SiK} \alpha$ の強度值 $x$ および
$\mathrm{FeK} \alpha$ の強度值 $z$ として, 3 個のタブレットの測定の平 均值を用いると, 標準偏差 $\sigma=0.29 \%$ となる.これは, 化学分析値の $\sigma(0.38 \%)$ に比べて, 寸ぐれた結果であ ることが示された.

すなわち， 6.1 の方法に加えて，この数式的方法を併 用することが最も正確度が高い分析法であることが結論 された.

Table VII Coefficients in the equation (1)

\begin{tabular}{|c|c|c|c|c|c|c|}
\hline $\begin{array}{r}\text { Win } \\
\text { vo }\end{array}$ & $\begin{array}{l}\text { dow } \\
\text { its }\end{array}$ & $a$ & $b$ & $c$ & $|c / b|$ & $\sigma$ \\
\hline \multirow{2}{*}{$30 \mathrm{~V}$} & $\left\{\begin{array}{l}x: \text { Intensity of } \operatorname{SiK} \alpha \\
z: \text { Intensity of } \mathrm{FeK} \alpha\end{array}\right.$ & 64.25 & 18.86 & -7.96 & 0.42 & 0.696 \\
\hline & $\left\{\begin{array}{l}x: \text { Intensity of } \mathrm{SiK} \alpha \\
z: \mathrm{Fe}_{2} \mathrm{O}_{3} \%\end{array}\right.$ & 62.82 & 20.29 & -8.59 & 0.43 & 0.654 \\
\hline \multirow{2}{*}{$15 \mathrm{~V}$} & $\left\{\begin{array}{l}x: \text { Intensity of } \operatorname{SiK} \alpha \\
z: \text { Intensity of } \mathrm{FeK} \alpha\end{array}\right.$ & 55.59 & 27.86 & -9.20 & 0.33 & $\begin{array}{l}0.396 \\
(0.286) \dagger\end{array}$ \\
\hline & $\left\{\begin{array}{l}x: \text { Intensity of } \mathrm{SiK} \boldsymbol{\alpha} \\
z: \mathrm{Fe}_{2} \mathrm{O}_{3} \%\end{array}\right.$ & 53.68 & 29.53 & -8.94 & 0.30 & 0.393 \\
\hline
\end{tabular}

$6 \cdot 3 \cdot 2$ 酸化アルミニウムの分析 $\mathrm{Al}_{2} \mathrm{O}_{3} \%(Y)$ 快 $\mathrm{A} 1 \mathrm{~K} \alpha$ の強度 $y$ および $\mathrm{FeK} \alpha$ の強度 $z$ との間に次式の 関係があると仮定した。

$$
Y=a+b y+c z
$$

（2）に扮ける定数 $a ， b ， c$ 恃重回帰分析により求め た。

（2）式は, 酸化ケイ素の場合と同じく，波高分析器の 二つの条件について求めた. 回帰分析から求めた定数お よび回帰からの標準偏差 $\sigma$ を Table VIII に示した.

また, 酸化ケイ素の場合と同様に, $y, z$ に 3 回のサン プリングの平均值を使用したが，この場合は $\sigma=0.42 \%$ となり，6.1 の場合に比べて改善されず，化学分析值の $\sigma(0.25 \%)$ に比べて, 著しく劣った.

Table VIII Coefficients in the equation (2)

\begin{tabular}{|c|c|c|c|c|c|c|}
\hline $\begin{array}{l}\text { Wind } \\
\text { vol }\end{array}$ & $\begin{array}{l}\text { dow } \\
\text { lts }\end{array}$ & $a$ & $b$ & $c$ & $|c / b|$ & $\sigma$ \\
\hline \multirow{2}{*}{$30 \mathrm{~V}$} & $\left\{\begin{array}{l}x: \text { Intensity of } \mathrm{AlK} \alpha \\
z: \text { Intensity of } \mathrm{FeK} \alpha\end{array}\right.$ & 6.12 & 16.68 & -8.59 & 0.515 & 0.628 \\
\hline & $\left\{\begin{array}{l}x: \text { Intensity of } \mathrm{AlK} \alpha \\
z: \mathrm{Fe}_{2} \mathrm{O}_{3} \%\end{array}\right.$ & 5.81 & 15.88 & -8.14 & 0.513 & 0.618 \\
\hline \multirow{2}{*}{$18 \mathrm{~V}$} & $\left(\begin{array}{l}x: \text { Intensity of } \mathrm{AlK} \alpha \\
z: \text { Intensity of } \mathrm{FeK} \alpha\end{array}\right.$ & 2.09 & 12.06 & -0.50 & 0.041 & $\begin{array}{l}0.590 \\
(0.419) \dagger\end{array}$ \\
\hline & $\left\{\begin{array}{l}x: \text { Intensity of } \mathrm{AlK} \alpha \\
z: \mathrm{Fe}_{2} \mathrm{O}_{3} \%\end{array}\right.$ & 1.38 & 12.19 & -0.10 & 0.008 & 0.585 \\
\hline
\end{tabular}

$\dagger$ Mean intensity values of three tables were used as $x, z$.

その理由は, $c / b$ の值の変化 (Table VIII) から知 られるように, すでに, 波高分析器により, 十分に酸化 鉄の影響が除かれていたためと考えられる。 


\section{7 分析時間}

酸化鉄, 酸化カルシウムの測定で 2 個繰返し, 酸化ケ イ素, 酸化アルミニウムの測定で 3 個繰返し, 各測定す るとして, 分析時間は (タブレット成型時間を含放て)約 35 分であった. 現在化学分析法では， 4 成分で約 3 時間 を要しているから,かなりの迅速化が期待される.

\section{交献}

1) G. Andermann : Anal. Chem., 33, 1689(1961).

2) 内川 浩, 猪股吉三, 井上 亨: 本誌, 11, 558 (1962).

3) J. F. Croke, W. R. Kiley : Norelco Reporter, 6, No. 1, 29 (1959).

4) H. Schloemer : Zement-Kalk-Gips, 13, 522 (1960).

5) 内川 浩, 猪股吉三, 井上 亨：本誌, 11,182 (1962).

is

Application of fluorescent $\mathrm{X}$-ray to rapid analysis of cement raw mix. Yasushi KAWASAKI* and Eiichi AsadA** (* Saitama Plant, Nihon Cement Co., Hidaka, Iruma-gun, Saitama, ** Government Chemical Industrial Research Institute, Tokyo,
Shibuya-ku, Tokyo)

Rapid determination of iron, silicon and aluminum in raw material clays and of calcium in limestone and slurry have been investigated by fluorescent X-ray method. Every specimens were prepared by pressing the powder in an aluminum ring for rapidity of operation.

1. Accuracies in determinations of iron and calcium were as high as those in chemical analyses' (Fig. 1, 2, Table IV).

2. The results on calcium determination were independent on differences in the brand of limestone. A calibration curve could be commonly used for limestone and slurry (Fig. 2).

3. Determination of silicon and aluminum was interfered by coexisting iron when ADP was used as the analyser crystal (Fig. 3, 4, 5). This was overcome by narrowering the slit width of pulse hight analyser. Or, in case of silicon, a correction factor obtained from multiple regression was introduced to give $\sigma=0.286 \%$. A combined use of both procedures gave better result.

4. Small variations in results for silicon and aluminum on each tablet preparation (Table V) indicated the necessity of repeated samplings. The might have been due to the extremely thin estimating layer of $\operatorname{SiK} \alpha$ and $\mathrm{AlK} \alpha$ (Table VI).

(Received Oct. 13, 1962)

\title{
金属テルル中のビスマスの吸光光度定量法
}

\author{
湯 浅 輝*
}

ジチゾンによるビスマスの财光光度定量法を検討し，金属テルル中の微量ビスマスの定量に応用した。

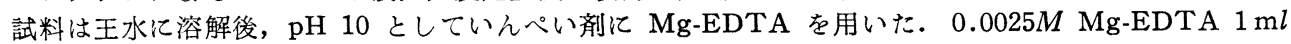
を加えると $100 \mu \mathrm{g}$ の鉛を容易にいんぺいするととができ，鉄，銅，覀鉛，ニッケルなども金属テルル 中に不純物として含まれる程度では妨害しない。

溶媒には, 従来多く用いられているクロロホルムよりも四塩化炭素が適し, 本法では $0.005 \%$ ヂゾ ン四塩化炭素溶液 $10 \mathrm{ml}$ を用い, 二層の分離後直接測定した。

実際の試料に応用して, 10 回の定量結果では平均 $5.42 \mu \mathrm{g}$ に対して標準偏差は $1.23 \%$ であり, 精 度がよく，しかも所要時間も 1 時間でたり，迅速法として適する。

\section{1 緒 言}

金属テルル中の不純物定量としては，すでに二，三の 方法を試みたが(1 4)，99.99\% 程度の金属テルル中には 微量のビスマスも分光学的に検出される.しかし，その 定量法はいまだ明らかにされていない.

* 住友電気工業(株) 研究部 : 大阪市此花区恩貴島南之 町
微量のビスマスの吸光光度法はジチゾン法をはじめ, カルバメート法5) 7), ヨウ素法8), チオシアン酸塩法9), 過塭素酸法10)などが知られている.これらのなかで妨害 元素および感度の点からみればジチゾン法が最もすぐれ ていると思われる。

本報では ジチゾン法によるビスマスの定量法を検討 し，分離を必要とせずに金属テルル中の微量のビスマス を迅速に定量することができたので報告する・すなわ 